\title{
The Female Working Citizen: \\ Social Rights, Work and Motherhood in Finland
}

Af Anneli Anttonen

Ideen om den kvindelige arbejdende medborger og det sociale moderskab er starkt indlejret $i$ finsk tankning. Har moderskab mistet betydninger for kvinders medborgerskab, eller lurer moderskabet stadigvak et eller andet sted $i$ en ny forkledning?

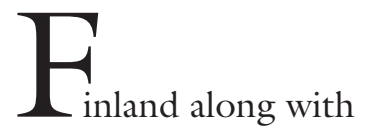

the other Nordic countries is known as a country, where women's right to paid work is well established and strongly supported by social policy. It is also often pointed out that women in Scandinavia have succeeded in extending social rights to cover such things as care of small children and older people. Finland, especially in the 1970 s and 1980s, has seen a huge expansion of social care services (Anttonen \& Sipilä 2000). A comprehensive municipal day-care system is a good example of this. All this means that women are able to combine their roles as mothers and workers. The idea of a working female citizen thus forms a major representation of femininity in Scandinavia. My aim in this article is firstly to locate the idea of a working female citizen in a historical context, and secondly to value its status in present-day Finnish society.

During the last decade feminist scholars have paid increasing attention to the concept of citizenship. They have asked: in 
which ways do women's citizenship differ from men's? Moreover, they have focused their analyses on the exclusionary processes through which women become defined as less valued citizens, or through which women's access to full citizenship has been restricted (see Lister 1997, Pateman 1989, Phillips 1993). They have also shown that struggles over full citizenship have followed similar routes in different countries. Especially, when looking at the period between the 1880s and 1950s, at least some kind of maternal discourse and politics can be identified in most western societies. Ruth Lister (1997, 176) sums up the debate on maternal citizenship by arguing that the "rhetoric of motherhood as national service" strongly channeled women's political and social action in the early phases of welfare state development.

In the Nordic countries the rhetoric of women's right to work seems to have a profound and unquestionable position, therefore, it is worthwhile asking: what is the status of maternalism and in which ways it is related to the idea of a female working citizen? When evaluating the situation in Finland, it is easy to conclude that maternalism has played a crucial historical role. Yet, we often think that maternalism which praises differences rather than similarities between men and women - lost its importance in the 1960s that marked a beginning for gender equality policy. My suggestion is, however, that the "rhetoric of motherhood as national service" became replaced by a "rhetoric of motherhood as personal choice". To give some evidence to this argument, I will end my article by looking at debates on childcare policy in Finland. My concluding notion is that the idea of a female working citizen is a contradictory representation that does not tell enough about women's different positions and desires in Finnish society.

\section{The IMAGE OF THE HARDWORKING FINNISH WOMAN}

"Too large a share of the labours of the field is thrown upon the weaker sex. A majority of those we saw thus employed were women. On a cold and lowering day we saw a Finn smoking in his house, and gazing through the window upon the field in front, where a woman was hard at work. A full share of indoor employment, including the spinning and weaving also falls, without doubt, to the females." (Op.sit. Markkola 1990, 17)

Women's hard work in the fields and later on building sites and in factories evoked astonishment among many foreign visitors already in the early $19^{\text {th }}$ century. In a slightly different way the 19th century literature in Finland constructed and repeated the story of the strong Finnish woman, who took part in production alongside the man.

"The stereotypical image of the ancestral mother of modern Finnish women, the country woman, includes an assumption of her strength and her almost equal status in relation to men", concludes Satu Apo (1999, 17). Like most stereotypes, the image of hard-working woman is only one side of the coin. Women's legal rights were much weaker in Agrarian Finland compared to those of men. It was only with the major reform of the marriage law in 1929 that all women were finally given an independent legal status (Markkola 1990, 20). However, one aim of the law was to strengthen the position of women especially in marriage by giving equal value for work done in the family, e.g. for housework and childcare.

The image of the strong Finnish woman is deeply rooted in the Agrarian legacy of the Finnish society. As late as in 190087 per cent of the population lived in the countryside, and two thirds of those economically active were in agriculture (Markkola 1990, 18). Another kind of explanation stresses the Lutheran cultural orthodoxy that includes the idea that work holds society together (Stenius 1997, Markkola 


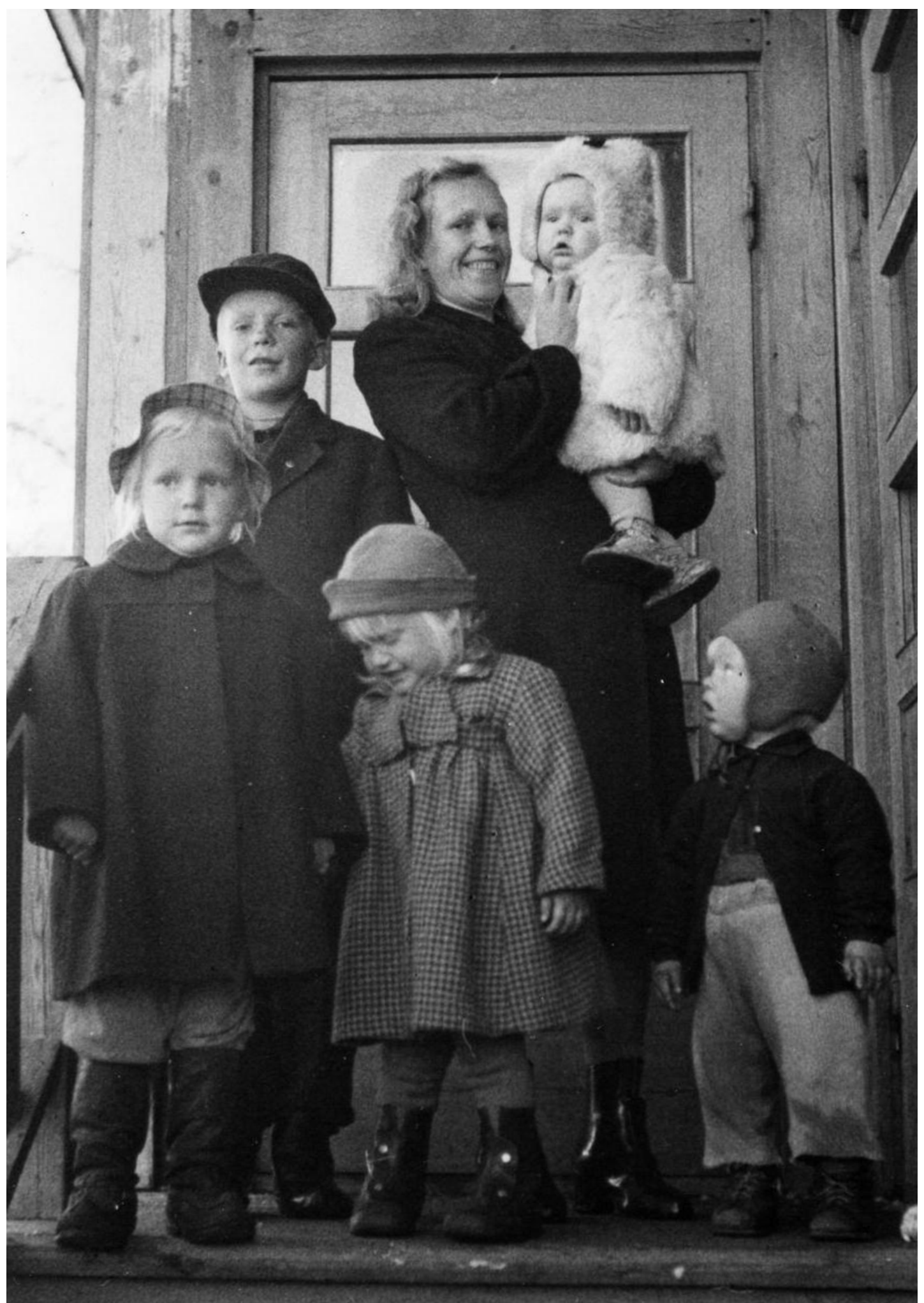


2001). Agrarianism and Protestantism have played important roles in the process of making the Finnish nation and its citizens. Compared to many other European countries industrialisation and urbanisation processes were delayed; we also have to remember that after Finland was separated from Sweden in war in 1809 it was an autonomous part of the Russian Empire until 1917. This again explains the strong nationalism in the emerging national state of Finland.

Since the early $19^{\text {th }}$ century, the construction of being a Finn was connected to nation state building. The transformation from loyal subjects to modern individuals was fuelled by the nationalist Fennomanian movement. In their struggle against Russification and the Swedish-speaking ruling elite, the upper classes had to gain a more powerful position in politics and in the emerging public sphere. In this struggle the elite needed the support of common people, of both men and women (Alapuro \& Stenius 1987). During the second half of the 19th century people's movements and associations were established along the rise of cooperative interest groups (Sulkunen 1990, 48). Irma Sulkunen has noted that "women took an active part in these nation-wide popular movements, often as the founders and leaders of local branches" (ibid. 49).

Through these movements the idea of a democratic citizenship was developed and implanted in the minds of common people. It was not only expressed in terms of civil and political rights, but included a strong moral commitment to the welfare of the whole nation. In Finland, the works of J.V. Snellman (1806-1881) and S. Alkio (18621930) share the heritage of the Danish N.F.S. Grundtvig (1783-1872) in their reliance on the power of education against ignorance and immorality. J.V. Snellman's conceptions of family, state and civil society were based on the Hegelian philosophy, where the state represents the most devel- oped level of moral reason. The HegelianSnellmanian moral reasoning reduced the plurality of particular subjects to a cultural unity leaving only a narrow space for individualism defined in terms of political liberalism.

The idea of a universal and democratic citizenship that will unify people, smoothen differences and de-politicise conflicts between classes, sexes and ethnic or language groups, however, turned out to represent an imaginary community. The governing upper classes faced an uprising by the working class and landless population. The Finnish Civil War in 1918 with German and Soviet military groups involved meant a political and mental crisis that froze the democratisation of civil society and paved the way to a strong centralised state that operate above all non-human drives. It also strengthened the idea of women as mothers for the nation. It was especially the working class women (read "working women") who had betrayed the national project. There were some women on the red side who took part in the armed battles. Moreover, after the civil war was over, communist women active in politics were sent to prison for years. A large number of red widows and orphaned children were impoverished, however, only those on the bourgeois side were entitled to widow's pensions and other allowances.

\section{MaKing Women's Nation: Social Motherhood as National Service}

According to Ruth Lister (1997, 176-194) the issues of maternal and child welfare formed the core of women's citizenship struggles earlier in history. Maternal citizenship discourse gives us one possible point of departure, when looking at the formation of women's citizenship in the context of welfare state development. It is, however, important to stress that motherhood never became an all-encompassing definer of womanhood. In Finland as elsewhere women's 
right to education and paid work were important goals in the women's rights movement already in the 19th century. Furthermore, women as well as children constituted a large part of the working population in the early stages of industrialisation. As I have said above, womanhood was defined in the 19th century rather through work than through mothering. In a historical context motherhood as an independent sphere of life was created later by modern science, especially by psychoanalysis (Vuori 2001).

"In our opinion a real woman is the one who, in answering the call of her heart, brings up, develops, cherishes, who cares for the frail and the weak ... In other words, femininity is motherhood in the deepest meaning of the word. That this be given its true value in that greatest of all homes, society, is the primary task of women's rights work, it is the essence of all our efforts, even though it is often misunderstood by our opponents and by our ostensible friends.” (Op.sit. Sulkunen 1990, 50-51)

Aleksandra Gripenberg, one of the first authorities in the Finnish Women's Right movement, wrote these words in the beginning of the $20^{\text {th }}$ century. The new national identity of a woman was bound to home, family and motherhood. Sulkunen (1991, 121) has argued that "the very concept of democratic citizen is and has always been gender-biased. It did not offer any promises of unshared equality: all the rights and the duties it implied tied down the citizenship of women primarily to the family and to the private, while the citizenship of men was accordingly linked up with the public and with working life."

Women's new status as mother-citizens was compatible with the social and political order advocated by J.V. Snellman. In Finland, what Irma Sulkunen (1987, 1990) calls social mothering strongly influenced women's citizenship struggle. Hence, even if excluded from the new moral agency, women took an active role in civil society and in building up the nation-state. They became integrated into the project of modernisation as different moral agents, women started to build up a women's nation (Pulkkinen 1998). By the turn of the 20th century, women had already taken a leading role in the field of social and health care organisations (Satka 1995).

Women's active role in civil society led to social policy reforms that had a special importance for women, children and the well-being of families. There are some good reasons to argue that the early development of Finnish social policy has a maternal origin as its background. During the first decades of the $20^{\text {th }}$ century, maternal policies were even in the centre of social reforms, although strongly influenced by poor law tradition and population policy. In the 1930s a law on maternity grant, addressed to poor women, entered into force. Furthermore, a special allowance for lowincome families with more than four children was introduced in 1943. Along the other Nordic countries in 1948 Finland got a universal child benefit that represents the first universal benefit in the history of Finnish social policy.

During the early decades of the $20^{\text {th }}$ century social motherhood was a hegemonic discourse shared by both bourgeois and working class women, but they did not aim at the same ends. Bourgeois women were deeply concerned about the increasing employment of women in factories, which was thought to be a serious threat to the morality not only of women themselves but also of homes, the future generations and society at large. For working-class women, in turn, maternal values were important, because motherhood was a social and economic risk at a time when no support systems for mothers existed. They strongly campaigned for social reforms to better women's situations both as mothers and workers.

The ideal of social motherhood did unify women on some issues, but did not solve 
the class question. Maternalism was built upon a hierarchical sisterhood, where upper-class women defined the content of womanhood. On the one hand there was a strong emphasis on mothering, on the other hand both the poor agrarian families and the more affluent industrial families needed the labour input of women. This contradiction became extremely visible right after the Finnish Civil War. According to the winners, the rebellious working class had betrayed the national project. Especially female widows and their children as well as thousands of orphaned children on the 'red' side were treated during the post-war decades as second-class citizens (Nätkin 1997). In this situation the bourgeois women's movement took a leadership in defining womanhood. Woman's role as a mother was celebrated more than before and maternal values became extremely important. The image of a strong working woman was put aside during the early decades of the $20^{\text {th }}$ century.

Social motherhood has been influential in the history of women's citizenship formation, although it proved to be partly imaginary. In Finland, the housewife institution never became very popular, because women had to work outside the home of economic necessity. The other side of the coin is that through paid work women have achieved the status of social citizen. In all societies social rights have strengthened the status of citizen more as a worker than as a mother (Leira 1992).

\section{Right TO Work AND Right TO}

Mother: STRUGgLe OVER ChILdCARE

Raija Julkunen (1999), among many other scholars, has argued that the Finnish women's movement has strongly advocated women's right to paid work outside the home. Yet, if we look at the historical formation of women's citizenship, it is easy to conclude that women's right to work became challenged by maternal politics and

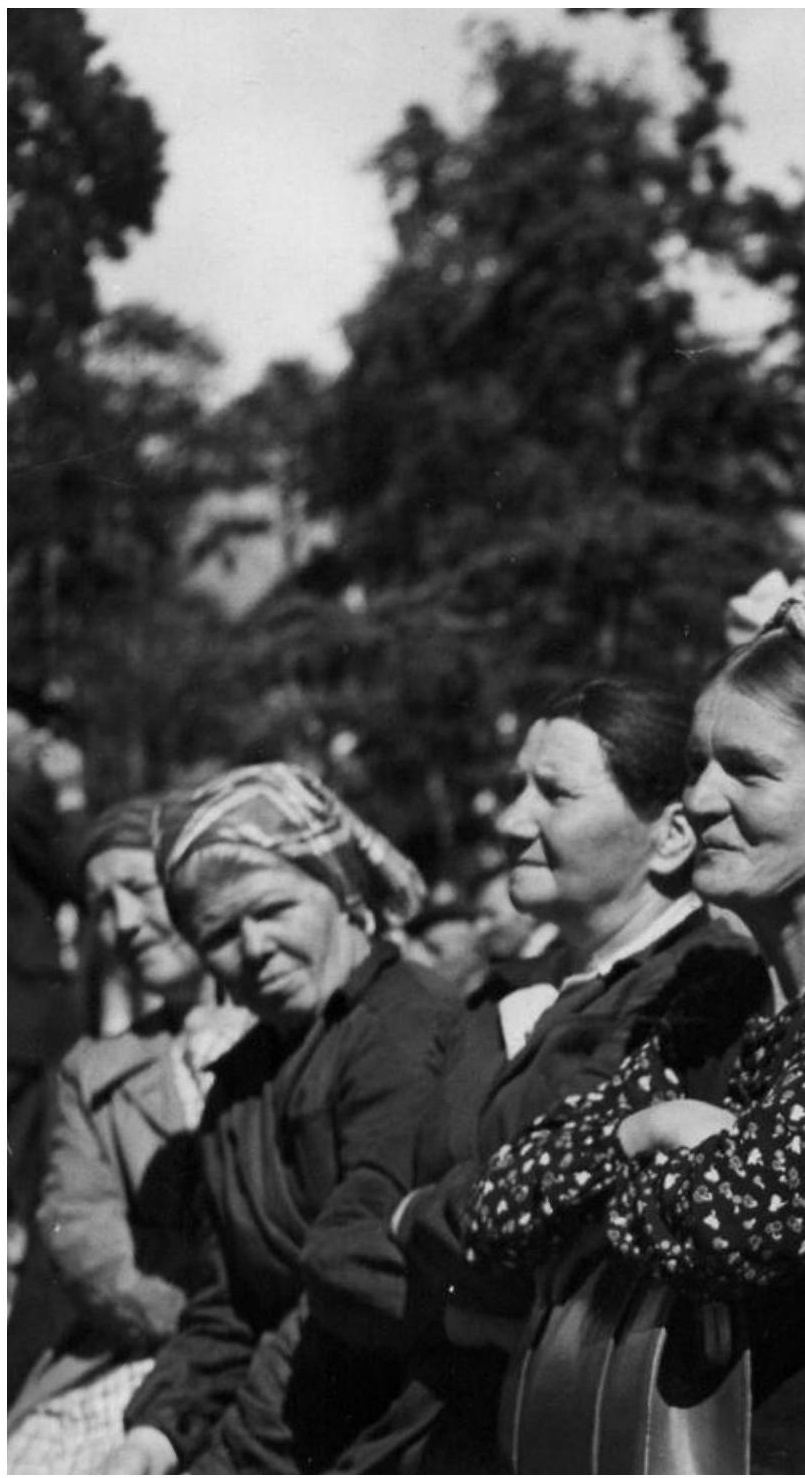

ideology. In the beginning of the $20^{\text {th }}$ century the rhetoric of "social motherhood as national service" replaced the earlier national image of "a hard-working Finnish woman". It was only in the 1960s that women's right to paid labour won a broader recognition in Finnish society. Accordingly, children's day-care became one of the most debated social policy issues.

Today the Nordic welfare states are well known for their generous provision of pub- 
care of their children under three years of age, and that most parents choose to benefit from the system of child home care allowance (CHCA) instead of using the right to municipal child care, we have to ask: is the idea of a female working citizen once again challenged by the "rhetoric of maternalism"?

My main argument is that when looking at the struggle over childcare policy in Finland, two contradictory discourses and policy lines can be identified. According to the first one, child day-care services are needed to guarantee women's right to paid labour and economic independence, while the second line of childcare policy wants to promote women's rights primarily based on the idea of mother-citizenship. All this suggests that the "rhetoric of materialism" did not lose once and forever its role as the definer of womanhood. It still has some importance, although in a slightly different form than earlier.

As I have already noted, the gender issue resurfaced in the mid 1960s, and as Anne Holli (1991) has argued the 1960s marked the beginning of a gender equality policy, which stressed the similarity of women and men: gender difference became a negatively loaded objective. The new task set for the state by the new women's movement was to facilitate the fitting together of wage labour and the home: there were increasing calls for better day-care services for children, for longer maternity leaves, and for the right of parents to stay at home to look after a sick child. In the centre of the struggles and campaigns led by the reorganised women's movement was the demand for a universal childcare system.

The history of children's day-care is in many ways parallel to the history of women's citizenship struggles. In the late 19th and in the early $20^{\text {th }}$ centuries kindergartens were not so much developed as a response to the needs of working women, but as institutions to support the role of homes and mothers as educators of new ge- nerations. The first kindergartens in Finland, dating back to the late 19th century, were privately owned or run by associations mainly led by women. They were motivated by feminist, pedagogic and poor-relief considerations, but the number of these early nursery schools never met the real need. The first calls for public day-care were made already in the beginning of the $20^{\text {th }}$ century. Yet, it took more than 50 years before the first national law on children's daycare entered into force (Rauhala 1996).

As late as in the 1950s the number of municipal kindergartens and crèches was still very low. Following the maternal ideology crèches were designed for mothers, who had to earn their living through paid work. The institution of crèches was closely connected to preventive poor-relief. They provided full-time care for low-income families, who "could not afford the mother to stay at home with their small children" the expression used in a number of official documents in the 1950s. Kindergartens, as mentioned above, were educationally oriented and provided mainly part-time care in the urban areas - most often run by welfare associations. More wealthy families could hire a nanny or domestic servant to take care of their children. Yet, in the $1950 \mathrm{~s}$ an increasing number of mothers with small children were moving out to take paid jobs. Moreover, there were less young women available for child minding due to better educational and work opportunities, and the signing of the modern welfare state opened up new professional choices for women as home-helpers, nurses and so on.

In the 1960s the level of women's labour market participation rose significantly and nearly 90 per cent of working women had full-time jobs. If women's labour market pattern changed fast, so did the pattern of political participation: during the 1960s the proportion of women in the Finnish parliament rose from 15 to 22 per cent. Moreover, it was with the debate on gender roles and the reorganisation of the women's mo- 
Table 1. Places in publicly funded day-care for children (0-7years) in Finland, 1965-1998

$\begin{array}{rrrr}\text { Year } & \text { Day-care centres } & \text { Family day-care } & \text { Total } \\ 1965 & & & \\ 1970 & 19.750 & 0 & 19.750 \\ 1975 & 28.195 & 0 & 28.195 \\ 1980 & 60.220 & 21.800 & 82.020 \\ 1985 & 83.670 & 47.970 & 131.640 \\ 1990 & 103.400 & 76.670 & 180.070 \\ 1995 & 118.030 & 95.850 & 213.880 \\ 1998 & 125.031 & 65.580 & 190.611 \\ & 142.776 & 75.746 & 218.524\end{array}$

(Source: Anttonen 1999, 65)

vement that the public debate on childcare began to gather too much momentum for the government's good. All together these factors set the day-care reform into motion.

Following a series of inevitable political disputes and compromises, the first National Day-care Act (1973) came to include two different elements: local authorities were charged with the responsibility to support, first, the building of day-care centres and, second, the supervision of day-care in families. The latter option was recorded in the law partly because the advocates of socalled mother's wage remained in the minority. The alternative suggested to the daycare line was that all mothers with children under school age would be paid a flat-rate allowance so that they themselves could decide whom they wanted to look after their child.

In the 1960s the debate on mother's wage was nearly as powerful as the debate on universal children's day-care. The debates of mother's wage and universal day-care for children formed two different discourses on childcare. They also represented two contradictory policy lines: the agrarian Centre Party promoted the idea of mothers' wage, while the political Left strongly supported the building of a nation-wide system of childcare centres. The National Day-care Act of 1973 was enacted by a coalition government, where Social Democrats were holding the prime power. They were backed by Communists as well as by many Liberals and some Conservatives (Rauhala 1996, 164-175). As mentioned above, the advocates of mother's wage did not succeed in getting the idea of flat-rate allowance through. Thus, mothers staying at home taking care of their small children were left without any financial support.

Since the introduction of the national day-care act, the municipal day-care system expanded very rapidly in Finland.

Table 1 tells us that until the early 1990s day-care places were steadily increasing, and Finland was gradually catching up with the coverage levels of Sweden and Denmark (Kröger 1997). The economic recession of the early 1990s caused a clear break to this development. Since 1994 day-care services have again continued their growth. The policy line adopted in 1973 did not, however, satisfy those, whose suggestion on mother's wage was left unanswered. The debate on alternative ways of supporting the care of small children was heated in the late 1970s and early 1980s. Interestingly, the notion of mother's wage was left behind and the concept of home care allowance was introduced. The latter notion expresses gender equality and gender neutrality rather than gender difference ('the home' instead of 'the mother').

In the mid 1980s the childcare legislation was revised and quite radically at that. There was still a chronic shortage of day- 
Table 2. Care of children under age three in Finland, 1985-1998 (children in day-care centres and in family day-care and those receiving home care allowances)

$\begin{array}{cccccc}\text { Year } & \begin{array}{c}\text { Day-care } \\ \text { centres }\end{array} & \begin{array}{c}\text { Family } \\ \text { day-care }\end{array} & \begin{array}{c}\text { Day-care } \\ \text { total }\end{array} & \begin{array}{c}\text { Families on } \\ \text { CHCA }\end{array} & \begin{array}{c}\text { Children } \\ \text { under 3 on } \\ \text { CHCA* }^{*}\end{array} \\ 1985 & 13.103 & 27.299 & 40.402 & 25.890 & \text { n.a. } \\ 1990 & 17.594 & 25.173 & 42.767 & 81.210 & \text { n.a. } \\ 1993 & 15.488 & 16.139 & 31.627 & 95.820 & 103.360 \\ 1995 & 16.392 & 16.296 & 32.688 & 84.476 & 89.807 \\ 1998 & 18.745 & 22.245 & 40.990 & 74.359 & 80.683\end{array}$

${ }^{*}$ Until 1992 receivers of the CHCA were registered only as families. (Sources: Sipilä \& Korpinen 1998, 268; Anttonen 1999, 67)

care places, and municipalities were unable to meet the increasing demands for childcare. The reform implemented in 1985 represented a historic compromise between the two competing policies. By accepting a proposal for a revised day-care act, the Centre Party won the backing it needed to get a system of CHCA adopted. The new legislation came to consist of two major parts. The Day Care Act of 1985 did not only require local governments to organise childcare services according to demand, it also established day-care as a legal right to parents of a child under the age of three.

The second part of the reform was just as radical. The Finnish parliament also passed a law which stipulated that as an alternative to a day-care place, parents of children under age three were to be given the option of taking a CHCA and using it either to look after their child themselves or to pay for private care (Sipilä \& Korpinen 1998, 263). At the same time the situation of parents who opted to stay at home, was facilitated by an amendment to the Contracts of Employment Act, which gave parents the right to take a childcare leave with full job security until the child is three years old.

Almost as soon as it was introduced, the CHCA became immensely popular. Already in 1987 the number of children in families choosing the allowance surpassed the number of children in the same age group in municipal day-care. The peak years in the popularity of the CHCA were seen in the early 1990s, when unemployment levels started to climb to a record high level of around 20 per cent. At the same time, the amount of the CHCA was at its highest so far. Moreover, a number of local governments were paying additional supplements to those receiving the $\mathrm{CHCA}$. At that time, nearly 70 per cent of children in the age group under three years of age were covered by the CHCA system, while less than 20 per cent of children in this age group were in municipal day-care.

As a result of the improving employment situation, the need for day-care has risen again since 1994 and correspondingly the number of children on CHCA has decreased. Moreover, in 1996 the government led by the Social Democrats cut the CHCA by more than 20 per cent, making it considerably less attractive. However, even at the end of 1997, 45 per cent of children under the age of three were in care arrangements subsidised by this benefit, and most (more than 90 per cent) were looked after at home.

In 1997 the CHCA was accompanied by a new benefit, children's private care allowance (CPCA), to be used by those families who prefer to purchase private day-care services. The CPCA is paid to families with children under school age. By this benefit nearly all forms of care arrangements for small children are now covered by public support. The introduction of CPCA signifi- 
es that the government now openly encourages private childcare provision. Moreover, the childcare policy line adopted during the last years is based on the rhetoric of parent's right to choose between different childcare arrangements.

\section{CONCLUSIONS}

The right to work has been an important goal for the Finnish women's movement. Yet, it would be misleading to argue that maternal values and politics have played only a minor part in feminist politics. Through the system of CHCA unpaid care work at home has won some recognition. It has, however, also fostered women's role as primary caretakers of their children. More than 90 per cent of parents staying at home are women, although one of the explicit aims of the childcare reform in 1985 was to promote gender equality and the father's care rights. On the one hand, there are some good reasons to argue that the idea of female working citizen has been shaken by the system of CHCA. On the other hand, it is important to stress that in Finland women do re-enter paid work. The number of women staying out of work at the time when their youngest child turns three is internationally very low (Salmi 2000). Moreover, as the option of part-time work does not really exist in Finland, women do fulltime work. In this situation the right to day-care is of great importance to women.

One result of the contemporary childcare policy is that a clear majority of Finnish children under the age of three are cared at home and nearly a third of children over three years of age. In this respect Finland differs from Sweden and Denmark, where nearly half of children under the age of three were in public day-care in 1996 (NOSOSCO 1998). When looking at the figures of children over the age of three, it is easy conclude that the coverage of day-care provision is internationally low, not only in comparison to Scandinavia but also when compared with countries like France, Germany and Italy, where nearly all children over the age of three are within some sort of provision (Rostgaard \& Fridberg 1998). And yet, the Finnish support system for childcare covers nearly every child and every kind of arrangement of care.

From a feminist point of view, motherhood proves to be a tricky issue. Should governments support women's personal choices to stay at home with their children financially? At least in Finland most women think there has to be a choice between working and mothering, when children are small. Especially for women in full-time work the opportunity to extend the period of maternal/parental leave (11 months) with some extra months is highly respected, although a clear majority of women who stay at home until the child is three years old are those of students, unemployed and less educated (Anttonen 1999, 71-76). Women constitute different groups and they value different choices. A crucial question for the feminist movement is: whose values matter the most?

\section{REFERENCES}

- Alapuro, Risto \& Stenius, Henrik (1987): "Kansanliikkeet loivat kansakunnan”, in R. Alapuro (ed.) Kansa liikkeessä Kirjayhtymä, Helsinki.

- Anttonen, Anneli (1997): "The Welfare State and Social Citizenship", in Kaisa Kauppinen \& Tuula Gordon (eds.) Unresolved Dilemmas: Women, Work and the Family in the United States, Europe and the former Soviet Union. Ashgate, Adershot.

- Anttonen, Anneli (1999): Lasten kotihoidon tuki suomalaisessa perhepolitiikassa. Kela, Sosiaali- ja terveysturvan tutkimuksia 52 , Helsinki.

- Anttonen, Anneli \& Sipilä, Jorma (1996): “European social care services: Is it possible to identify models? ", in Journal of European Social Policy 1996/6: 2 .

· Anttonen, Anneli \& Sipilä, Jorma (2000): Suomalaista sosiaalipolitiikaa. Vastapaino, Tampere. - Apo, Satu (1999): "The Mythic Woman", in Women in Finland. Otava, Helsinki.

- Daly, Mary \& Lewis, Jane (2000): “The concept of social care and the analysis of contemporary welfare states", in British Journal of Sociology 2000/51: 2. 
- Holli, Anne (1991): Miehisestä tasa-arvosta kohti naisten käsitteellistämisen tilaa. Tasa-arvoasian neuvottelukunnan tasaarvopoliittinen diskurssi. Lisensiaatintutkimus. Helsingin yliopisto yleinen valtio-oppi, Helsinki.

- Julkunen, Raija (1999): “Gender, Work, Welfare State", in Women in Finland. Otava, Helsinki.

. Kröger, Teppo (1997): "The dilemma of municipalities: Scandinavian approaches to child day-care provision", in Journal of Social Policy 1997/26 4. - Leira, Arnlaug (1992): Welfare States and Working Mothers. Cambridge University Press, Cambridge.

- Lister, Ruth (1997): Citizenship: Feminist Perspectives. Macmillan, Basingstoke.

- Markkola, Pirjo (1990): "Women in Rural Society in the $19^{\text {th }}$ and $20^{\text {th }}$ centuries", in M. Manninen \& P. Setälä (eds.) The Lady with the Bow. The Story of Finnish Women. Otava, Helsinki.

- Markkola, Pirjo (2001): "Lutheranism and the Nordic Welfare States in Gender Perspective", in Kvinder, Køn \& Forskning 2/2001.

- NOSOSCO (1998): Social Protection in the Nordic Countries 1996: Scope, Expenditure and Financing. NOSOSCO, Copenhagen.

- Nätkin, Ritva (1997): Kamppailu suomalaisesta äitiydestä. Gaudeamus, Helsinki.

- Pateman, Carole (1989): The disorder of women.

Standford University Press, Standford.

- Phillips, Anne (1993): Democracy and Difference.

Polity Press, Cambridge.

- Pulkkinen, Tuija (1998): Postmoderni politiikan filosofia. Gaudeamus, Helsinki.

- Rauhala, Pirkko-Liisa (1996): Miten sosiaalipalvelut ovat tulleet osaksi suomalaista sosiaaliturvaa? University of Tampere, Tampere.

- Rostgaard, Tine \& Fridberg, T. (1998): Caring for Children and Older People: A Comparison of European Policies and Practices. The Danish National Institute of Social Research, Copenhagen.

- Salmi, Minna (2000): "Analysing the Finnish homecare allowance system: challenges to research and problems of interpretation", in N. Bruun \& L. Kalliomaa-Puha (eds.) Work and Family: Report on New Perspectives of Equality in the Nordic Countries. Nordiska Ministerrådet, Copenhagen.

- Satka, Mirja (1995): Making Social Citizenship. Conceptual practices from the Finnish Poor Law to professional social work. Publications on Social and Political Sciences and Philosophy. University of Jyväskylä, Jyväskylä.

- Sipilä, Jorma \& Korpinen, Johanna (1998): “Cash versus child care services in Finland", in Social Policy \& Administration 1998/32:3.

- Stenius, Henrik (1997): "Konformitetsideal blev universalitetsprincip", in G. Bexell \& H. Stenius (red.) Värdetraditioner i nordiskt perspektiv. Lund University Press, Lund.

- Sulkunen, Irma (1987): "Naisten järjestäytyminen ja kaksijakoinen kansalaisuus", in R. Alapuro (ed.) Kansa liikkeessä Kirjayhtymä, Helsinki.

. Sulkunen, Irma (1990): "The Mobilization of Women and the Birth of Civil Society", in M. Manninen \& P. Setälä (eds.) The Lady with the Bow. The Story of Finnish Women. Otava, Helsinki. - Sulkunen, Irma (1991): Retki naishistoriaan. Hanki ja Jää, Helsinki.

- Vuori, Jaana (2001): Äidit, isät ja ammattilaiset. Sukupuoli, toisto ja muunnelmat asiantuntijoiden kirjoituksissa. Vastapaino, Tampere.

\section{SUMMARY}

The article presents an account and an analysis of the struggle for women's citizenship in Finland. The central analytical tool is the concept of a female working citizen that seems to be a major representation of femininity in the Finnish society. The article traces the idea of the working female citizen in a historical context. It argues that the construction of the hard working woman was challenged by the "rhetoric of motherhood as national service" in the beginning of the $20^{\text {th }}$ century. The article explores the construction and practice of maternal citizenship in the emerging Finnish welfare state and concludes that motherhood has played a crucial role in the struggle for women's citizenship rights. Furthermore, it argues that the 1960s marked the beginning of a gender equality policy that redefined the idea of a female working citizen. Yet, the "rhetoric of motherhood as national service" was not totally abandoned but replaced by a "rhetoric of motherhood as personal choice". In order to trace this argumentation, the author looks at the debates on childcare policy in Finland. The article concludes that the idea of a female working citizen is a contradictory representation of femininity both historically and presently.

Anneli Anttonen, Ph.D., senior lecturer, Department of Social Policy and Social Work, University of Finland 